\title{
The evidence and role of music therapy in addressing the resilience of adolescents with eating disorders in the context of an acute inpatient admission
}

\author{
Sarah Punch \\ From 2013 ANZAED Conference: Inspiring Change: Person and Context \\ Melbourne, Australia. 23-24 August 2013
}

Engaging in music is an integral part of identity formation and coping during adolescence. For a population who are establishing their place in the world, music serves as a medium for peer interaction, social acceptance and connectedness (McFerran, 2010). The effectiveness of music therapy with the adolescent population has been well documented (Baker, McFerran-Skewes \& Krout, 2011). In particular, the use of familiar and unfamiliar songs provides a powerful platform for adolescents to express and share parts of their identity, communicate their feelings, as well as discover hope and guidance.

Drawing on the evidence, this paper will outline the ways that a music therapy program strives to improve coping for adolescents with an eating disorder within an acute paediatric inpatient setting and once discharged. This will be highlighted through case vignettes and patient perspectives.

The music therapy program outlined in this paper is an integral part of the multidisciplinary treating team and works closely alongside medical and nursing staff to address the needs of young people with eating disorders.

This abstract was presented in the Care in Inpatient and Community Settings stream of the 2013 ANZAED Conference.

Published: 14 November 2013

Correspondence: sarah.punch@southernhealth.org.au

Monash Health, Australia

(C) 2013 Punch; licensee BioMed Central Ltd. This is an Open Access article distributed under the terms of the Creative Commons Attribution License (http://creativecommons.org/licenses/by/2.0), which permits unrestricted use, distribution, and reproduction in any medium, provided the original work is properly cited.
doi:10.1186/2050-2974-1-S1-016

Cite this article as: Punch: The evidence and role of music therapy in addressing the resilience of adolescents with eating disorders in the context of an acute inpatient admission. Journal of Eating Disorders 2013 1(Suppl 1):016.
Submit your next manuscript to BioMed Central and take full advantage of:

- Convenient online submission

- Thorough peer review

- No space constraints or color figure charges

- Immediate publication on acceptance

- Inclusion in PubMed, CAS, Scopus and Google Scholar

- Research which is freely available for redistribution 